Економічні науки: збірник наукових пращь Луцького національного технічного університету. Серія "Регіональна економіка". Випуск 17 (67). Редкол.: відп. ред. к.е.н., професор І.В. Кривов’язюк. Луцьк: ІВВ Луцького НТУ, 2020. 348 с.

УДК 339

Галазюк Н.М., к.е.н., доцент

Зелінська О.М., к.е.н., доцент

Луцький національний технічний університет

\title{
ТРАНСФОРМАЦІЯ СВІТОВОЇ ФІНАНСОВОЇ СИСТЕМИ: ТЕНДЕНЦІЇ ТА ПЕРСПЕКТИВИ РОЗВИТКУ СУЧАСНИХ ФІНАНСОВИХ РИНКІВ
}

Сучасна наукова література представлена цілим рядом дослідницьких праць, пов'язаних 3 формуванням, трансформацією і зміцненням конструкції світової фінансової архітектури, проте вони нерідко носять безсистемний i миттєвий характер з явним політизованим відтінком. У зв'язку з цим, питання аналізу i системного концептуального осмислення перспектив розвитку світової фінансової системи на сучасному етапі розвитку глобальної економіки $€$ різнорідними за своєю теоретико-методологічною основою: в науководослідному i експертному співтоваристві існують принципово неузгоджені теоретичні та практичні відмінності в підходах, що обумовлює необхідність в аргументації мети і завдань даного дослідження.

Ключові слова: світова фінансова система, фінансова глобалізація, фінансове середовище, глобальний капітал, національна фінансова система.

\section{Galazyk N., Zelinska O.}

\section{TRANSFORMATION OF THE WORLD FINANCIAL SYSTEM: TRENDS AND PROSPECTS OF DEVELOPMENT OF MODERN FINANCIAL MARKETS}

The current stage of development of the global economy is characterized by the acceleration of the processes of financial globalization, which qualitatively and quantitatively change its institutional environment, as well as the relationship and interdependence of all components of the global financial system. These changes are ambiguous and contradictory. On the one hand, there is a reduction in the cost of interstate financial cooperation and, as a consequence, increase the efficiency of redistribution of global capital and increase the growth rate of national economies.

The global crisis has exposed all the key problems of the global financial architecture related to its unipolar structure "led" by the US dollar. It has virtually exhausted its potential and is no longer able to provide adequate answers to the challenges posed by the world economy: its unipolarity is in sharp contrast to the multipolarity of the global economy, which is already beginning to strengthen the position of developing countries. The article analyzes the prospects for reforming the global financial system, which are quite relevant. 
Економічні науки: збірник наукових прачь Луиького національного технічного університету. Серія "Регіональна економіка". Випуск 17 (67). Редкол.: відп. ред. к.е.н., професор І.В. Кривов’язюк. Луцьк: ІВВ Луцького НТУ, 2020. 348 с.

It should be noted that the global crisis has forced to return to the theoretical and practical legacy left in the past by economists, who stood at the origins of the international financial system, given that already developed scientific methods and practices have failed in overcoming the shock of financial stability. -economic systems.

Currently, modern scientific literature is represented by a number of research papers related to the formation, transformation and strengthening of the global financial architecture, but they are often unsystematic and instantaneous with a clear politicized tone. In this regard, the issues of analysis and systematic conceptual understanding of the prospects for the global financial system at the present stage of global economic development are heterogeneous in their theoretical and methodological basis: in the research and expert community there are fundamentally inconsistent theoretical and practical differences in approaches; which necessitates the argumentation of the purpose and objectives of this study.

Key words: world financial system, financial globalization, financial environment, global capital, national financial system.

Галазюк Н.Н., Зелинская О.Н.

\section{ТРАНСФОРМАЦИЯ МИРОВОЙ ФИНАНСОВОЙ СИСТЕМЫ: ТЕНДЕНЦИИ И ПЕРСПЕКТИВЫ РАЗВИТИЯ СОВРЕМЕННЫХ ФИНАНСОВЫХ РЫНКОВ}

Современная научная литература представлена целым рядом исследовательских работ, связанных с формированием, трансформацией и укреплением конструкции мировой финансовой архитектуры, однако они нередко носят бессистемный и мгновенный характер с явным политизированным оттенком. В связи с этим, вопросы анализа и системного концептуального осмысления перспектив развития мировой финансовой системы на современном этапе развития глобальной экономики являются разнородными по своей теоретико-методологической основой: в научноисследовательском и экспертном сообществе существуют принципиально согласованы теоретические и практические различия в подходах, что обусловливает необходимость в аргументации целей и задач данного исследования.

Ключевые слова: мировая финансовая система, финансовая глобализация, финансовая среда, глобальный капитал, национальная финансовая система.

Постановка проблеми у загальному вигляді і її зв'язок 3 важливими науковими та практичними завданнями. Домінантою глобалізаційних процесів виступає фінансова глобалізація, яка якісно і кількісно змінює середовище світової 
Економічні науки: збірник наукових прачь Луиького національного технічного університету. Серія "Регіональна економіка". Випуск 17 (67). Редкол.: відп. ред. к.е.н., професор І.В. Кривов'язюк. Луиьк: ІВВ Луцького НТУ, 2020. 348 с.

фінансової системи. Формування глобального фінансового ринку замість сукупності ряду національних фінансових ринків наочно ілюструє ці зміни.

Разом 3 тим глобальний характер фінансового ринку несе позитивний імпульс лише в умовах стабільності, проте циклічний характер економічного розвитку пов'язаний 3 нестабільністю, яка підсилює негативні явища, породжувані глобальним фінансовим ринком. Саме тому дослідження особливостей інституційного розвитку світової фінансової системи обумовлено сучасними реаліями і обумовленими ними зрушеннями в науковій парадигмі соціальних досліджень.

Аналіз останніх досліджень, у яких започатковано вирішення проблеми. Світова фінансова система представляє собою багатогранний i комплексний об'єкт вивчення, цим зокрема пояснюється різноманітність теоретичних та практичних напрацювань щодо даної тематики дослідження. Тому не випадково, що існують різні підходи до ії визначення.

В першу чергу, ряд вчених в своїх трактуваннях СФС робить акцент на міжнародних валютно-кредитних і фінансових відносинах як основа системи, а також формулюють загальне уявлення про об'єкт наукового аналізу через розкриття суті його базових елементів - різних міжнародних фінансових ринків.

По-друге, деякі дослідники прирівнюють СФС 3 певною формою організації міжнародних фінансових відносин в рамках спеціальних узгоджених принципів та концентрують увагу на інститутах, які є ключовими ланками системи.

Також, в окремих роботах автори звертаються, головним чином, до складеного елементу структури МФС, а саме до світової валютної системи, тобто в основу дефініції об'єкта дослідження закладають взаємодію i взаємовплив його компонентів.

На різних етапах дослідження в залежності від рівня i характеру розв'язуваних науково-практичних завдань використовуються загальнонаукові і спеціальні методи пізнання, включаючи логічні методи (аналіз, синтез, індукцію, дедукцію та аналогію), теоретичні (дедуктивний, узагальнення, 
Економічні науки: збірник наукових прачь Луиького національного технічного університету. Серія "Регіональна економіка". Випуск 17 (67). Редкол.: відп. ред. к.е.н., професор І.В. Кривов'язюк. Луиьк: ІВВ Луцького НТУ, 2020. 348 с.

факторний, системний методи), емпіричні методи (порівняння, математичне моделювання), спеціальні (монографічне обстеження, економіко-статистичний аналіз).

Застосовується міждисциплінарний підхід, що поєднує інструментарій як економічної науки, так і ряду інших суміжних дисциплін, і дозволяє провести системний аналіз досліджуваних об'єктів. Теоретичною основою послужили фундаментальні положення класичної економічної науки, науково-теоретичні дослідження i розробки в області світової економіки i глобальних фінансів, фінансової глобалізації, регулювання міжнародних фінансово-економічних відносин, сформульовані в працях провідних зарубіжних і вітчизняних вчених, доповідей:
А. Анікіна,
А. Булатова,
О. Буторіной,
С. Горбунова,
В. Васільева,
Р. Зіменкова,
Е. Кіріченко,
І. Королева,
Л. Красавіной,
В. Курьерова,
Л. Лебедевой,
М. Максімовой,
В. Марцінкевіча,
С. Мойсєєва,
Н. Лівенцева, А. Пороховского, С. Рогова.

Цілю даної статті $€$ виявлення та теоретикометодологічне обгрунтування парадигми формування перспектив розвитку світової фінансової системи в рамках інституційного та функціонально-управлінського підходу.

Виклад основного матеріалу дослідження 3 повним обгрунтуванням отриманих наукових результатів. Безумовно, що для кожної країни забезпечити сталий економічний розвиток, фінансову стабільність та збільшити рівень життя населення - одне $з$ першочергових та важливих завдань. Це роблять за допомогою виваженої політики у всіх структурах держави, враховуючи певні особливості соціальних, економічних, національних, політичних систем. Значний досвід багатьох країн показує про вагому роль в розвитку держави, адекватної політики в макроекономічних сферах, а також про високий рівень наявності кваліфікованих працівників та покращення рівня технологічного розвитку, розширення інвестицій (особливо з-за кордону), та присутність стабільних фінансових інститутів. 
Економічні науки: збірник наукових прачь Луиького національного технічного університету. Серія "Регіональна економіка". Випуск 17 (67). Редкол.: відп. ред. к.е.н., професор І.В. Кривов'язюк. Луиьк: ІВВ Луцького НТУ, 2020. 348 с.

Головною ознакою практично всіх високорозвинених країн являється приналежність до світового економічного та фінансового простору. Процес фінансової глобалізації, який пришвидшується взаємоучастю національних фінансових систем, описує СФС таким чином: це об’єднаний комплекс, який має свої певні характеристики, риси та фактори зростання. Тобто, фінансова глобалізація - це спрямований процес націлений на формування цільного фінансового ринку, який зосереджений на міжнародному русі капіталу.

Фінансова глобалізація спричинює нові відносини, які виникають 3 приводу перерозподілу фінансових ресурсів на міжнародному ринку. Вона включає певні конкретні національні економіки задля фінансових процесів. Те, що ці процеси бувають неоднозначними, то виникають як і позитивні, так i негативні наслідки для певних національних економік. Міжнародний валютний фонд провів дослідження, що вказує, що не тільки є «традиційні» вигоди:

- зростання ВВП;

- зростання ефективності в розміщенні капіталу;

- міжнародний поділ ризику;

- накопичення капіталу;

- зменшення рівня волатильності споживання.

А й містяться «додаткові» вигоди:

- розвиток інституційної сфери;

- розвиток фінансової сфери;

- макроекономічна дисципліна;

- покращення управління, тощо.

До основних видів вигод від інтеграції країни в СФС слід віднести: економічне зростання, диверсифікація ризику, оптимізація в розміщенні капіталу, зростання ефективності та розвитку національних фінансових систем та зростання ефективності та розвитку національних фінансових інститутів.

Структура та форма міжнародних рухів капіталу, які відносяться до тої чи іншої країни, беззаперечно впливають на розмір впливу від фінансової інтеграції. 
Економічні науки: збірник наукових прачь Луиького національного технічного університету. Серія "Регіональна економіка". Випуск 17 (67). Редкол.: відп. ред. к.е.н., професор І.В. Кривов'язюк. Луиьк: ІВВ Луцького НТУ, 2020. 348 с.

Наприклад, короткостроковий борговий капітал вважається найризикованішим, бо він доволі швидко витікає 3 економіки у випадку фінансової нестабільності чи фінансових криз тощо.

А якщо залучати міжнародні ресурси під виглядом прямих інвестицій, це навпаки найвигідніший варіант, через досвід в управлінні, ноу-хау, технологічний розвиток.

«3'являються нові вимоги, що стосуються монетарної політики та банківської системи, через нові тенденції, які відносяться до світової економіки. Через світову фінансову кризу, ми можемо спостерігати, що велика кількість фінансових інститутів не готова до праці в нестальному економічнозовнішньому та економічно-внутрішньому середовищі. Також, в більшості науковці та експерти і державні та міжнародні інститути нездатні передбачати та прогнозувати фінансові кризи»[1].

Дж. Стігліц вважає, що пояснення, яке ми отримуємо після кризи, буде спростоване наступною кризою, чи буде вказувати, що попереднє пояснення є недоцільним.

Сьогодні, світовий фінансовий простір можна представити як комплекс таких об'єктів, що представлено на рисунку 1.

«Перехід від «індустріальної економіки» до «економіки знань» спричиняють певні перебудови в структурі світової економіки.

Нинішній стан банківської системи в світовій економіці показує те, що банківський сектор це головний суб'єкт на грошовому ринку. Звідси слідує, що глобалізація нинішнього суспільства, спричиняє необхідність у вдосконаленні фінансової системи» [3].

Тому, основне завдання для фінансових ринків - дати можливість певним суб' єктам своєчасно реагувати на зміни, що стосуються внутрішнього та зовнішнього середовища.

Шенг Е. зазначив, що банківська система, яка була заснована в основному на депозитних продуктах, і спрямовувала свою діяльність на фінансуванні кредитних коштів на потреби позичальників, змінилася на складну систему постачання, яка 
Економічні науки: збірник наукових прачь Луиького національного технічного університету. Серія "Регіональна економіка". Випуск 17 (67). Редкол.: відп. ред. к.е.н., професор І.В. Кривов’язюк. Луцьк: ІВВ Луцького НТУ, 2020. 348 с.

піддається так званому «ефекту доміно» в ризиках дестабілізації (наприклад ситуація в Японії весною 2011 року).

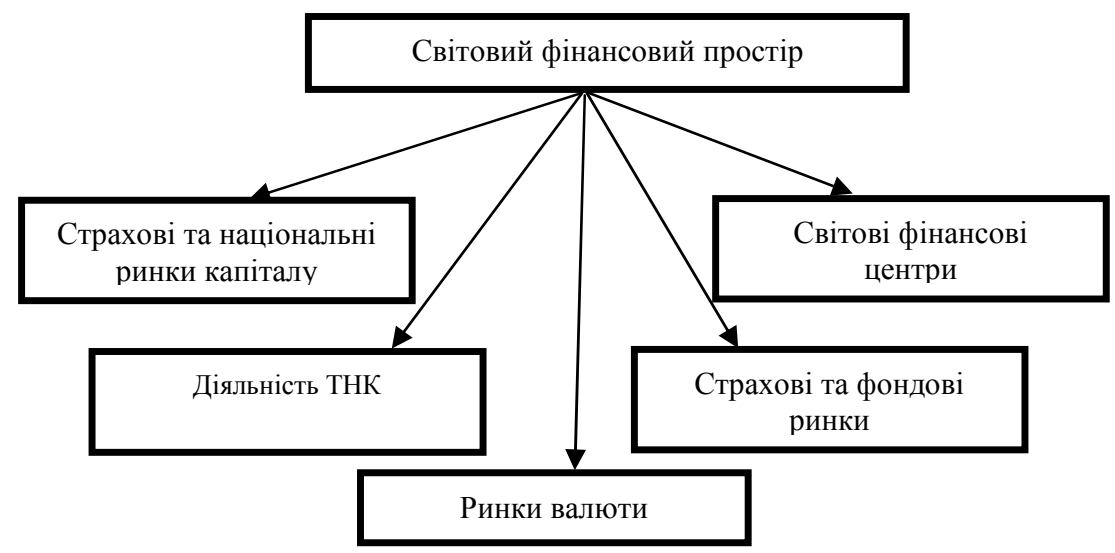

Рис. 1. Комплекс об'єктів, що належать до світового фінансового простору

Джерело: побудовано за [2].

Шенга Е. представив еволюцію фінансового постачання, що ділиться на:

- Фінансова архітектура;

- Механізм зворотного зв'язку.

Дж. Стігліц визначив під час небезпек, що мали місце в 2012 році, що навіть до кризи була так звана корекція 200-річної аномалії, під час якої частина у світовому ВВП, яка належить Азії знизилась практично до рівня меншого $10 \%$ з 50\%.

Дії монетарної європейської політики сприяють нинішнім тенденціям азійського зростання, і це призводить до зниження ефективності у зростанні економіки в Свропі.

«Якщо розглядати проблеми країн Свропи, що є нині, то видно, що це впливає на ефективність в сфері монетарної політики. Навіть на певні позитивні зміни, що стосуються фінансових ринків, фінансова стабільність дещо послабіла, і це 
Економічні науки: збірник наукових прачь Луиького національного технічного університету. Серія "Регіональна економіка". Випуск 17 (67). Редкол.: відп. ред. к.е.н., професор І.В. Кривов’язюк. Луцьк: ІВВ Луцького НТУ, 2020. 348 с.

спричинено низьким рівнем довіри пов'язаною 3 світовою фінансовою системою»[4].

Контроль над бюджетним дефіцитом $є$ головним принципом фінансової політики держав Європи, та це можна назвати ефективним виходом з фінансових криз.

Звідси слідує, що є потреба в оцінці зв'язку між такими показниками: дефіцит державного бюджету, загальна грошова база держави та фінансовою кризою. Наприклад, перед кризою такі держави як Ірландія та Іспанія мали профіцит бюджету, а Сполучені штати Америки - бюджетний дефіцит.

Тому, фіскальна політика та фінансова дисципліна не $є$ такими вже ефективними в розв'язані кризових питань. Економіка не отримує стимуляцію від бюджетного дефіциту.

Тому, монетарна політика держави має займатися питаннями, що відносяться до короткострокових періодів. А фіскальна політика грає важливу роль в довгострокових перспективах.

Тобто, чітка теорія, яка пояснить причини, які створюють фінансові кризи та можливість передбачити змінені наслідки, відсутня, навіть якщо досліджувати зв'язок між економічними змінними та грошовими величинами в економіці.

«Можна стверджувати, що ефективність держави в економічній сфері напряму залежить від можливості пристосування до динамічних змін. Першочерговою ціллю має стати винайдення новітньої грошової теорії, яка має містити економічні змінні, і вони, в свою чергу, мають мати зв'язок 3 грошовими величинами»[5].

«Також можна зазначити, що модернізація та превентивні заходи впливу неспроможні в повній мірі подолати фінансові кризи. Цінність валюти в часі постійно зменшується, тому що ніяка валюта не спроможна бути пов'язаною як товар власною цінністю.

Перспективно надалі досліджувати ефективні механізми, що стосуються управління ризиками з фінансами (в основному для банківського сегменту в економіці). 
Економічні науки: збірник наукових прачь Луиького національного технічного університету. Серія "Регіональна економіка". Випуск 17 (67). Редкол.: відп. ред. к.е.н., професор І.В. Кривов'язюк. Луиьк: ІВВ Луцького НТУ, 2020. 348 с.

А також необхідно розробляти нову фінансову парадигму, а не тільки в загальному розглядувати як функціонує фінансова система.

Нова фінансова теорія має мати основою нову теорію грошей, та має мати нові еквіваленти вартості»[6].

«Можна виділити такі принципи, на яких має формуватися еволюція фінансових ринків:

- для досліджуваної проблеми слід мати міру сучасності (точку відліку);

- визначити критерії для відбору новіших механізмів для здійснення практичної політики в економіці.

- не допустити, щоби в один і той же час були обмежені так звані «коридори свободи» через які корегуються пріоритети в макроекономічних чи інституціональних теоріях»[7].

Світова фінансова система наразі характеризується зменшенням надконцентрації фінансового капіталу, та збільшення індивідуалізму. Наприклад, 40\% світового багатства зосереджено в руках 147 суб'єктів глобальної фінансової економіки.

«Перспектива в глобалізації, що пов’язана 3 фінансовим ринком - це безумовно нагальна конкуренція їх цивілізаційних шансів. Звичайно, що глобалізація не значить, що держави світу просто стають учасниками якогось світового простору»[8].

«Адже, у світовому просторі занадто серйозна конкуренція за кращі «місця», тому найкращій варіант задля досягнення передової позиції, це безумовно через досягнення в інноваційно-інформаційному просторі, які утворюються при умові збалансованого об'єднання ринку та мережевоінформаційної економіки. Саме у цих параметрах заданих глобалізаційною перспективою розвиваються нинішні фінансові ринки»[9].

Висновки. За результатами аналізу перспектив реформування світової фінансової системи запропоновано зробити наступні кроки: розробити нові правила діяльності провідних світових рейтингових агентств і встановити контроль над ними; збільшити легітимність наявних фінансових 
Економічні науки: збірник наукових прачь Луиького національного технічного університету. Серія "Регіональна економіка". Випуск 17 (67). Редкол.: відп. ред. к.е.н., професор І.В. Кривов'язюк. Луиьк: ІВВ Луцького НТУ, 2020. 348 с.

інститутів; зміцнити світову фінансову систему за рахунок створення світових фінансових центрів і безлічі резервних валют; удосконалювати систему управління ризиками на основі «гармонізованої системи міжнародних і національних стандартів у діяльності учасників фінансових ринків», створити багатополярну систему управління міжнародними організаціями; сформувати новий центр сили об'єднанням зусиль Росії і Китаю, 80 приєднання до них країн ШОС, створення своєї валютно-фінансової системи, створення регіональної банківської системи, власних рейтингових агентств, введення єдиної регіональної валюти; зберегти вільний вибір будь-якого режиму валютного курсу, що відповідає принципам після кризового розвитку світової економіки, заснованим на лібералізмі і на міждержавному регулюванні; закріпити стандарт використання золота як міжнародного резервного активу і визначити принципи регулювання операцій iз золотом центральних банків, щоб виключити різкі коливання його ціни з урахуванням уроків сучасної кризи. Що, однак, не означає повернення до золотомонетному стандарту. Перспективо надалі досліджувати ефективні механізми, що стосуються управління ризиками 3 фінансами (в основному для банківського сегменту в економіці). А також необхідно розробляти нову фінансову парадигму, а не тільки в загальному розглядувати як функціонує фінансова система.

\section{Список бібліографічного опису}

1. Financial Globalization: A Reappraisal. M.A. Kose, E.Prasad, K. Rogoff, S.J. Wei / International Monetary Fund Working Paper WP/06/189/ 2006. 94 p.

2. Офіційний сайт Національної комісії $з$ цінних паперів та фондового ринку України URL: http:// nssmc.gov.ua/.

3. Офіційний веб-сайт Державної служби статистики України URL:http://www.ukrstat.gov.ua/

4. Румянцев А.П., Голюк В.Я., Тонких О.Г. "Міжнародні фінансові відносини": Навч. пос. К.: Центр учбової літератури, 2008. 348 с

5. Герасименко О. Збалансування фінансової системи держави / Фінанси України, 2016.

6. Берлач А.І., Корпенко Д.О., Ковальський В.С. Правознавство: Підручник, /за ред. Копєйчикова В.В., Колодія А.М./ К.: Юрінком Інтер, 2016. 752. 
Економічні науки: збірник наукових прачь Луиького національного технічного університету. Серія "Регіональна економіка". Випуск 17 (67). Редкол.: відп. ред. к.е.н., професор І.В. Кривов’язюк. Луцьк: ІВВ Луцького НТУ, 2020. 348 с.

7. Ковальчук А.Т. Фінансове право України. Стан та перспективи розвитку. /К.: Парламентське вид-во. 2007. 488 с. 347 c.

8. Осіпчук Л.Л. Фінанси: Підручник для студ. ВНЗ. К.: МАУП, 2004.

9. Капаєва Л.М., Лях М.С. Фінансове право: Навчальний посібник. Київ: Центр навчальної літератури, 2004. 248 с.

10. Стукало Н.В. Особливості сучасного трактування термінів «фінанси» та «фінансова система» / Науковий вісник Волинського державного університету ім. Л. Українки. Економічні науки, №1, 2006.

\section{References}

1. Financial Globalization: A Reappraisal / M.A. Kose, E.Prasad, K. Rogoff, S. J. Wei / International Monetary Fund Working Paper WP/06/189/ 2006. $94 \mathrm{p} /$ [in English].

2. Ofitsiynyy sayt Natsional'noyi komisiyi z tsinnykh paperiv ta fondovoho rynku Ukrayiny URL: http:// nssmc.gov.ua/ [in Ukrainian].

3. Ofitsiynyy veb-sayt Derzhavnoyi sluzhby statystyky Ukrayiny URL:http://www.ukrstat.gov.ua/ [in Ukrainian].

4. Rumyantsev A.P., Holyuk V.Ya., Tonkykh O.H. "Mizhnarodni finansovi vidnosyny": Navch. pos. K.: Tsentr uchbovoyi literatury, 2008. 348 s / [in Ukrainian].

5. Herasymenko O. Zbalansuvannya finansovoyi systemy derzhavy / Finansy Ukrayiny, 2016. / [in Ukrainian].

6. Berlach A.I., Korpenko D.O., Koval's'kyy V.S. Pravoznavstvo: Pidruchnyk, /za red. Kopyeychykova V.V., Kolodiya A.M./ K.: Yurinkom Inter, 2016. 752. / [in Ukrainian].

7. Koval'chuk A.T. Finansove pravo Ukrayiny. Stan ta perspektyvy rozvytku. /K.: Parlament-s'ke vyd-vo. 2007. 488 s. / [in Ukrainian].

8. Osipchuk L.L. Finansy: Pidruchnyk dlya stud. VNZ. K.: MAUP, 2004. $347 \mathrm{~s} /$ [in Ukrainian].

9. Kapayeva L.M., Lyakh M.S. Finansove pravo: Navchal'nyy posibnyk. Kyyiv: Tsentr navchal'noyi literatury, 2004. 248 s. / [in Ukrainian].

10. Stukalo N.V. Osoblyvosti suchasnoho traktuvannya terminiv «finansy» ta «finansova systema»/ Naukovyy visnyk Volyns'koho derzhavnoho universytetu im. L. Ukrayinky. Ekonomichni nauky, \#1, 2006. / [in Ukrainian]. 